\title{
QUANTUM-MECHANICAL EVALUATION OF ADDITIVITY INCREMENTS FOR CONFORMATIONAL ENERGIES: CHLOROALKANES
}

\author{
D. Šatkovskienė, P. Pipiraitė, R. Jankauskas, and J. Šulskus \\ Department of Theoretical Physics, Faculty of Physics, Vilnius University, Sauletekio 9, LT-10222 Vilnius, Lithuania \\ E-mail: dalia.satkovskiene@ff.vu.lt
}

Received 22 September 2003; revised 26 March 2004

\begin{abstract}
The ability of quantum-mechanical methods (HF/6-31G and MP2) to estimate additivity increments $E_{\mathrm{G}}^{\mathrm{XY}}\left(\mathrm{X}, \mathrm{Y}=\mathrm{CH}_{3}, \mathrm{Cl}\right)$, $E_{\mathrm{GT}}^{\mathrm{XY}}, E_{\mathrm{GG}}^{\mathrm{XY}}, E_{\mathrm{GG}}^{\mathrm{XY}}(\mathrm{X}=\mathrm{Y}=\mathrm{Cl})$ for conformational energies in chloro-substituted saturated hydrocarbons has been studied. Various basis sets including those extended by different sets of polarization functions both on heavy atoms ( $1 d, 2 d, 3 d, 2 d 1 f$, $3 d 1 f)$ and on hydrogens $(1 p, 2 p, 3 p)$ have been examined. The obtained results have been compared with available experimental data. It is shown that only the results obtained using the MP2 method and basis sets with polarization functions are in the scope with experimental estimates. The relative arrangement of conformational energies for various conformers in the series of polysubstituted chloroalkanes obtained using the additivity rule as well as direct quantum-mechanical calculations coincide with experimental findings. This fact can be considered as an argument that it is possibile to work out quantum-mechanically based additivity schemes for haloalkanes.
\end{abstract}

Keywords: additivity, conformational energies, chloroalkanes

PACS: $33.15 . \mathrm{Bh}$

\section{Introduction}

The conformational analysis plays an extremely important role in biological processes. For example, the character of interactions and structure of the products in a plenty of biochemical reactions essentially depends on the conformations of the interacting compounds. However, the determination of the relative arrangement of conformational energies for large compounds is a complicated problem. The simplest examples of mentioned molecules often used as models for conformational investigations are haloalkanes. It is known that the conformational stability of conformers depends on the localization and electronegativity of the substitutes. However, the experimental values of conformational energies are known only for the first members of homologous series of haloalkanes and reveal a considerably large scatter.

In our previous paper [1] the perturbation theory for one-electron density matrix was applied to study the additivity of conformational energies of saturated molecules. It has been shown that the conformational energy of saturated compounds can be presented as a sum of transferable increments corresponding to the energies of separate conformational segments and their sequences:

$$
\begin{aligned}
E^{\mathrm{conf}}= & E-E^{\mathrm{T}} \\
= & n_{G}^{\mathrm{XY}} E_{G}^{\mathrm{XY}}+n_{T G}^{\mathrm{XY}} E_{T G}^{\mathrm{XY}} \\
& +n_{G G}^{\mathrm{XY}} E_{G G}^{\mathrm{XY}}+n_{G G^{\prime}}^{\mathrm{XY}} E_{G G^{\prime}}^{\mathrm{XY}}+\cdots,
\end{aligned}
$$

where $E$ is the total energy of a molecule in the given conformation, $E^{\mathrm{T}}$ is the total energy of the molecule in the lowest energy conformation, $E_{G}^{\mathrm{XY}}, E_{G T}^{\mathrm{XY}}, E_{G G}^{\mathrm{XY}}$, $E_{G G^{\prime}}^{\mathrm{XY}}\left(\mathrm{X}, \mathrm{Y}=\mathrm{CH}_{3}, \mathrm{Cl}, \mathrm{F}, \mathrm{Br}\right.$, etc. $)$ are the energies of the corresponding additivity increments, $n$ denotes the number of the corresponding segments in the given conformation. The mentioned result provides the theoretical background for the so-called additivity systematic and allows one to use Eq. (1) for predicting the relative conformational energies for saturated compounds. However, evaluation of the additivity increments using experimental data becomes a problem because of the considerably large scatter of the latter. In [2] we studied the possibility to evaluate the additivity increments for saturated hydrocarbons $\left(\mathrm{X}=\mathrm{Y}=\mathrm{CH}_{3}\right)$ using quantum-mechanical methods. It was shown that 
$a b$ initio methods qualitatively reflect the main features of additivity increments: the independence of location and the length of the molecule, the stabilizing role of the $G G$ segment etc. However, it was shown that only methods with dispersion forces "switched on" satisfying the criterion $E_{G}+2 E_{G G}>0$ can be used for evaluation of the additivity increments. The purpose of the present paper is to study the ability of various quantummechanical methods and basis sets available to estimate the increments corresponding to the energies of separate conformational segments and their sequences for saturated chloroalkanes. Especially, as it was noted in [3], the bond and the group additivity schemes often used for the prediction of heats of formation may be in error as halogens are introduced into the molecule.

\section{Computational methods}

Computations were performed both at the HartreeFock level and with account of electron correlation using the second-order Møller-Plesset perturbation theory (MP2). The computational chemistry packages PC GAMESS version [4] and GAMESS (US) [5] were used. The standard geometry optimization was performed for all investigated structures at the HartreeFock as well as at MP2 level. To determine the basis set and the level of computations necessary to achieve correct qualitative and possibly quantitative results for conformational energies of chloroalkanes, the main atomic basis set 6-311G as well as extended basis sets using different polarization functions both on heavy atoms $(1 d, 2 d, 3 d, 2 d 1 f, 3 d 1 f)$ and on hydrogens ( $1 p$, $2 p, 3 p)$ were used.

\section{Results and discussion}

\subsection{Determination of calculation resources and evaluation of additivity increments}

One can find three types of gauche increments in chloroalkanes $E_{G}^{\mathrm{XY}}$ corresponding to $\mathrm{X}=\mathrm{Y}=\mathrm{CH}_{3}$, $\mathrm{X}=\mathrm{CH}_{3}, \mathrm{Y}=\mathrm{Cl}$, and $\mathrm{X}=\mathrm{Y}=\mathrm{Cl}$. The first type has been estimated quantum-mechanically in [2]. In order to estimate the energies of the additivity increments $E_{G}^{\mathrm{XY}}\left(\mathrm{X}=\mathrm{CH}_{3}, \mathrm{Y}=\mathrm{Cl}\right.$, and $\left.\mathrm{X}=\mathrm{Y}=\mathrm{Cl}\right)$ it is necessary to calculate the total energy difference for gauche and trans conformers of 1-chloropropane and 1,2-dichloroethane, respectively.

The experimentaly determined values of energy difference $E_{G}-E_{T}$ for 1-chloropropane in the vapour

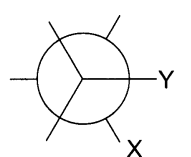

G

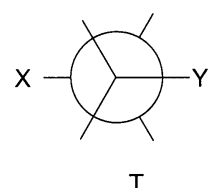

$\mathrm{T}$
Fig. 1. Newman projections for conformations of 1-chloropropane $\left(\mathrm{X}=\mathrm{Cl}, \mathrm{Y}=\mathrm{CH}_{3}\right)$ and 1,2-dichloroethane $(\mathrm{X}, \mathrm{Y}=\mathrm{Cl})$.

phase $(+0.02$ to $-0.47 \mathrm{kcal} / \mathrm{mol}[6,7])$ show the existence of considerable uncertainity as to which conformer is more stable. Moreover, the obtained results vary in the large range of experimental errors. The most recent conformational studies in the vapour state by infrared spectroscopy gives the trans/gauche energy difference to be $0.09 \pm 0.02 \mathrm{kcal} / \mathrm{mol}$ [8], confirming the gauche conformer (Fig. 1) being more stable. The corresponding enthalpy difference of $0.15 \pm 0.01 \mathrm{kcal} / \mathrm{mol}$ in liquid krypton has been reported in [9]. As the two conformers have similar dipole moments and molecular volumes, the latter result should be close to the value in the vapour state.

The calculations with full geometry optimization performed using HF/6-31G $(d)$, MP2/6-31G $(d)$, LMP2 methods, and GVB-LMP2 calculations with extended basis set (cc-pVTZ $(f)$ ) and geometry optimization performed using MP2/6-31G $(d)$ gradient optimization $[9,10]$ gave incorrect result, i.e. the trans form of 1-chloropropane being more stable than gauche. However, the calculations using larger basis sets with full geometry optimization by MP2/6-311+G $(d, p)$ and MP2/6-311+G $(2 d, 2 p)$ methods gave the results for conformer stabilities close to the experimental findings [9].

Thus, the brief overview of earlier theoretically obtained results shows that the conformational studies for small chloroalkanes require sufficiently accurate calculations. Therefore, the determination of the method and basis sets allowing reliable evaluation of the energy increment $E_{G}^{\mathrm{XY}}\left(\mathrm{X}=\mathrm{Cl}, \mathrm{Y}=\mathrm{CH}_{3}\right)$ with possibly lower cost of computations was the first task of our calculations. For this purpose we compared results obtained by HF and MP2 methods with full geometry optimization using various basis sets.

The calculations performed using $\mathrm{HF} / 6-31 \mathrm{G}(d)$ give the value $E_{G}-E_{T}=0.36 \mathrm{kcal} / \mathrm{mol}$. MP2 $/ 6-31 \mathrm{G}(d)$ calculations with $\mathrm{HF} / 6-31 \mathrm{G}(d)$ geometry improve the result to $0.15 \mathrm{kcal} / \mathrm{mol}$, and $\mathrm{MP} 2 / 6-31 \mathrm{G}(d)$ calculations with geometry optimization diminuate the value to $0.11 \mathrm{kcal} / \mathrm{mol}$. However, in all mentioned cases the result has an incorrect sign. This points out that the basis set might be insufficiently large. The re- 
Table 1. RCE $\left(E_{G}-E_{T}\right)$ and structural parameters (bond lengths $R$, valence angles $\varphi$, dihedral angles $\vartheta$, and dipole moments $\mu$ ) for trans and gauche conformations of 1-chloropropane.

\begin{tabular}{|c|c|c|c|c|c|c|c|}
\hline $\begin{array}{l}\text { Method and } \\
\text { basis set }\end{array}$ & $\begin{array}{c}R(\mathrm{X}-\mathrm{C}) \\
(\AA)\end{array}$ & $\begin{array}{c}R(\mathrm{C} 1-\mathrm{C} 2) \\
(\AA)\end{array}$ & $\begin{array}{c}R(\mathrm{C} 2-\mathrm{C} 3) \\
(\AA)\end{array}$ & $\begin{array}{c}\varphi(\mathrm{XCC}) \\
(\mathrm{deg})\end{array}$ & $\begin{array}{c}\vartheta(\mathrm{XCCC}) \\
(\mathrm{deg})\end{array}$ & $\begin{array}{c}\mu \\
\text { (Debye) }\end{array}$ & $\begin{array}{c}E_{G}-E_{T} \\
(\mathrm{kcal} / \mathrm{mol})\end{array}$ \\
\hline \multicolumn{8}{|l|}{$1-\mathrm{ClC}_{3} \mathrm{H}_{7}(G)$} \\
\hline $\mathrm{HF} / 6-311 \mathrm{G}(3 d 1 f)$ & 1.797 & 1.519 & 1.524 & 112.5 & 66.9 & 2.270 & 0.33 \\
\hline $\mathrm{HF} / 6-311 \mathrm{G}(3 d 1 f 3 p)$ & 1.797 & 1.518 & 1.524 & 112.6 & 66.8 & 2.283 & 0.33 \\
\hline MP2/6-311G & 1.902 & 1.525 & 1.539 & 111.3 & 66.6 & 2.541 & 0.07 \\
\hline $\mathrm{MP} 2 / 6-311 \mathrm{G}(2 d)$ & 1.811 & 1.511 & 1.519 & 111.9 & 64.8 & 2.149 & -0.21 \\
\hline $\mathrm{MP} 2 / 6-311 \mathrm{G}(2 d 1 p)$ & 1.808 & 1.515 & 1.523 & 111.8 & 64.7 & 2.063 & -0.22 \\
\hline MP2/6-311G(2d2p) & 1.806 & 1.514 & 1.522 & 111.7 & 65.0 & 2.046 & -0.15 \\
\hline MP2/6-11G(2d1f1p) & 1.792 & 1.513 & 1.520 & 111.7 & 64.4 & 2.029 & -0.19 \\
\hline $\mathrm{MP} 2 / 6-311 \mathrm{G}(2 d 1 f 2 p)$ & 1.791 & 1.513 & 1.520 & 111.6 & 64.8 & 2.016 & -0.15 \\
\hline $\mathrm{MP} 2 / 6-311 \mathrm{G}(3 d)$ & 1.796 & 1.515 & 1.522 & 111.7 & 65.5 & 2.077 & -0.05 \\
\hline MP2/6-311G(3d1f) & 1.787 & 1.516 & 1.522 & 111.6 & 65.5 & 2.055 & -0.22 \\
\hline MP2/6-311G(3d1f3p) & 1.785 & 1.515 & 1.521 & 111.6 & 64.8 & 1.994 & -0.24 \\
\hline Exp. data [7] & 1.796 & 1.525 & 1.525 & 112.2 & 63.9 & $1.960[8]$ & $-0.15[9]$ \\
\hline \multicolumn{8}{|l|}{$1-\mathrm{ClC}_{3} \mathrm{H}_{7}(T)$} \\
\hline $\mathrm{HF} / 6-311 \mathrm{G}(3 d 1 f)$ & 1.794 & 1.518 & 1.527 & 111.7 & 180.0 & 2.373 & \\
\hline $\mathrm{HF} / 6-311 \mathrm{G}(3 d 1 f 3 p)$ & 1.794 & 1.517 & 1.527 & 111.7 & 180.0 & 2.381 & \\
\hline MP2/6-311G & 1.898 & 1.525 & 1.545 & 110.7 & 180.0 & 2.659 & \\
\hline $\mathrm{MP} 2 / 6-311 \mathrm{G}(2 d)$ & 1.808 & 1.510 & 1.523 & 111.6 & 180.1 & 2.251 & \\
\hline $\mathrm{MP} 2 / 6-311 \mathrm{G}(2 d 1 p)$ & 1.804 & 1.514 & 1.527 & 111.6 & 180.1 & 2.177 & \\
\hline MP2/6-311G $(2 d 2 p)$ & 1.803 & 1.512 & 1.526 & 111.6 & 180.1 & 2.164 & \\
\hline MP2/6-311G(2d1f $1 p)$ & 1.789 & 1.512 & 1.523 & 111.5 & 180.1 & 2.142 & \\
\hline $\mathrm{MP} 2 / 6-311 \mathrm{G}(2 d 1 f 2 p)$ & 1.788 & 1.512 & 1.523 & 111.5 & 180.1 & 2.135 & \\
\hline $\mathrm{MP} 2 / 6-311 \mathrm{G}(3 d)$ & 1.792 & 1.514 & 1.525 & 111.6 & 180.1 & 2.213 & \\
\hline MP2/6-311G(3d1f) & 1.784 & 1.515 & 1.525 & 111.4 & 180.1 & 2.190 & \\
\hline $\mathrm{MP} 2 / 6-311 \mathrm{G}(3 d 1 f 3 p)$ & 1.782 & 1.514 & 1.524 & 111.4 & 180.1 & 2.114 & \\
\hline Exp. data [7] & 1.794 & 1.522 & 1.522 & 113.3 & 180.0 & $2.020[8]$ & \\
\hline
\end{tabular}

sults obtained for 1-chloropropane using extended basis sets with several polarization functions of $d$ - and $f$-type on heavy atoms and $p$-type on hydrogens and core orbitals frozen are presented in Table 1. The relative conformational energy (RCE) value, which coincides in that case with the additivity increment $E_{G}^{\mathrm{XY}}$ $\left(\mathrm{X}=\mathrm{Cl}, \mathrm{Y}=\mathrm{CH}_{3}\right)$, obtained in $\mathrm{HF}$ calculations has an incorrect sign and almost does not depend on the number of polarization functions included. Thus, it can be concluded that influence of electron correlation for conformational energy is very important. The comparison of structural parameters obtained using MP2 when polarization functions are taken into account are in sufficiently good agreement with experiment [7], whereas the results obtained by HF/6-311G(3d1f3p) and MP2/6-311G without polarization functions give too high dipole moment $(\mu)$ values. Consequently it might be expected that only the MP2 method with polarization functions for all basis sets used is in the scope of largely scattered experimental estimates [6]. Therefore, for further calculations we confine ourselves by two basis sets: (i) the largest one, 6-311G( $3 d 1 f 3 p)$, which gives the dipole moment value close to experimental and demonstrates saturating behaviour of RCE when $3 p$ basis functions on hydrogen atoms are added to the $3 d 1 f$ basis set and (ii) the least one, $2 d 2 p$, in which the RCE value coincides with the most recent experimental result [9] and which is sufficiently compact for calculations of large molecules.

1,2-dichloroethane is the molecule for which the largest number of experimental gas phase studies are available. The results obtained by several techniques (electron diffraction, infrared and photoelectron spectroscopy) show the trans conformer having a lower energy. The average value of the gaucheltrans energy difference $E_{G}-E_{T}$ proposed in [11] equals $1.1 \pm 0.1 \mathrm{kcal} / \mathrm{mol}$. The most recent value of $1.17 \pm 0.04 \mathrm{kcal} / \mathrm{mol}$, redetermined in [8] using infrared spectra, agrees with the above value within the error limits.

The theoretical estimates of gauche/trans energy difference by HF/6-31G* and DFT methods give too large values $(1.91 \mathrm{kcal} / \mathrm{mol}[12]$ and $1.51 \mathrm{kcal} / \mathrm{mol}[10])$. The second-order Møller-Plesset perturbation theory (MP2) improves the values of a lot of molecular properties as compared to the HF theory, e. g., equilibrium geometries, dipole moments, and conformational energy differences, if sufficiently large basis sets are ap- 
Table 2. RCE $\left(E_{G}-E_{T}\right)$ and structural parameters (bond lengths $R$, valence angles $\varphi$, dihedral angles $\vartheta$, and dipole moments $\mu$ ) for trans and gauche conformations of 1,2-dichloroethane.

\begin{tabular}{|c|c|c|c|c|c|c|c|}
\hline $\begin{array}{l}\text { Method and } \\
\text { basis set }\end{array}$ & $\begin{array}{c}R(\mathrm{X}-\mathrm{C}) \\
(\AA)\end{array}$ & $\begin{array}{c}R(\mathrm{C}-\mathrm{C}) \\
\quad(\AA)\end{array}$ & $\begin{array}{c}R(\mathrm{H}-\mathrm{C}) \\
(\AA)\end{array}$ & $\begin{array}{c}\varphi(\mathrm{XCC}) \\
(\mathrm{deg})\end{array}$ & $\begin{array}{c}\vartheta(\mathrm{XCCX}) \\
(\operatorname{deg})\end{array}$ & $\begin{array}{c}\mu \\
\text { (Debye) }\end{array}$ & $\begin{array}{c}E_{G}-E_{T} \\
(\mathrm{kcal} / \mathrm{mol})\end{array}$ \\
\hline \multicolumn{8}{|l|}{$1,2-\mathrm{Cl}_{2} \mathrm{C}_{2} \mathrm{H}_{4}(G)$} \\
\hline MP2/6-311G & 1.886 & 1.512 & 1.091 & 112.0 & 71.0 & 3.35 & 2.12 \\
\hline $\mathrm{MP} 2 / 6-311 \mathrm{G}(2 d)$ & 1.797 & 1.503 & 1.090 & 112.2 & 68.2 & 2.81 & 1.47 \\
\hline MP2/6-311G $(2 d 2 p)$ & 1.793 & 1.506 & 1.085 & 112.1 & 68.3 & 2.69 & 1.51 \\
\hline $\mathrm{MP} 2 / 6-311 \mathrm{G}(3 d)$ & 1.782 & 1.509 & 1.092 & 112.0 & 68.2 & 2.70 & 1.39 \\
\hline MP2/6-311G(3d1f) & 1.775 & 1.510 & 1.090 & 111.7 & 67.8 & 2.68 & 1.12 \\
\hline MP2/6-311G(3d1f3p) & 1.773 & 1.509 & 1.089 & 111.8 & 67.5 & 2.61 & 1.18 \\
\hline Exp. data & & & & & $68-76[14]$ & $2.55[15]$ & $1.1[11]$ \\
\hline \multicolumn{8}{|l|}{$1,2-\mathrm{Cl}_{2} \mathrm{C}_{2} \mathrm{H}_{4}(T)$} \\
\hline MP2/6-311G & 1.896 & 1.513 & 1.087 & 108.2 & 180 & 0 & \\
\hline MP2/6-311G(2d) & 1.804 & 1.505 & 1.087 & 108.8 & 180 & 0 & \\
\hline MP2/6-311G(2d2p) & 1.799 & 1.507 & 1.083 & 108.9 & 180 & 0 & \\
\hline $\mathrm{MP} 2 / 6-311 \mathrm{G}(3 d)$ & 1.788 & 1.510 & 1.090 & 108.9 & 180 & 0 & \\
\hline MP2/6-311G(3d1f) & 1.779 & 1.512 & 1.088 & 108.9 & 180 & 0 & \\
\hline MP2/6-311G(3d1f3p) & 1.778 & 1.511 & 1.087 & 109.0 & 180 & 0 & \\
\hline Exp. data [14] & 1.790 & 1.531 & 1.112 & 109.0 & 180 & 0 & \\
\hline
\end{tabular}<smiles>CC1(C)C(Cl)C2(C)C(C)(C)C1(C)C2(C)C</smiles>

TT<smiles>CC1(C)C(Cl)C2(Cl)CCC1(C)C2(C)C</smiles>

GG

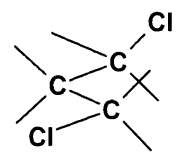

TG

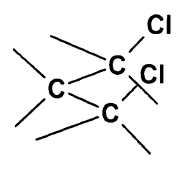

GG'
Fig. 2. Conformations of 1,3-dichloropropane.

plied. The local MP2 method [13] combined with the generalized valence bond approach (GVB-LMP2) with cc-pVTZ $(-f)$ basis set reported in [10] gives $1.40 \mathrm{kcal} / \mathrm{mol}$. In order to improve the results, Wiberg et al. [11] carried out geometry optimization using the MP2 method with several basis sets where diffuse functions were included: MP2/6-31+G $\mathrm{G}^{* *}$, MP2/6-311+G* MP2/6-31++G** However, the conformational energy difference remained too large. Only the inclusion of higher angular momentum $f$-functions allowed us to reach the energy difference value in agreement with experimental data $(1.1 \pm 0.1 \mathrm{kcal} / \mathrm{mol})$.

Therefore, in order to estimate the conformational energy increment $E_{G}^{\mathrm{XY}}(\mathrm{X}=\mathrm{Y}=\mathrm{Cl})$ we performed calculations using the MP2 method with different basis sets. The obtained results for 1,2-dichloroethane are presented in Table 2. The difference of conformation energy $E_{G}-E_{T}$ converges to the experimental value [11] when the basis set $6-311 \mathrm{G}(3 d 1 f 3 p)$ is used. The calculations with other basis sets show worse coin- cidence with experimental findings for the dipole moment $\mu$ of the gauche conformer, geometrical parameters, and RCE.

The calculations of $G G, G G^{\prime}, G T$, and $T T$ forms of 1,3-dichloropropane (Fig. 2) give the possibility to estimate the energy increments $E_{G G}^{\mathrm{XX}}, E_{G T}^{\mathrm{XX}}$, and $E_{G G^{\prime}}^{\mathrm{XX}}$ $(\mathrm{X}=\mathrm{Cl})$. As it follows from Eq. (1) for this case,

$$
\begin{aligned}
& E_{G T}^{\mathrm{XX}}=E_{G T}-E_{T T}-E_{G}^{\mathrm{XY}}, \\
& E_{G G}^{\mathrm{XX}}=E_{G G}-E_{T T}-2 E_{G}^{\mathrm{XY}}, \\
& E_{G G^{\prime}}^{\mathrm{XX}}=E_{G G^{\prime}}-E_{T T}-2 E_{G}^{\mathrm{XY}},
\end{aligned}
$$

where $\mathrm{X}=\mathrm{Cl}, \mathrm{Y}=\mathrm{CH}_{3}$.

RCE values $E_{G T}-E_{T T}$ and $E_{G G}-E_{G T}$ obtained at the HF/6-31G $(d)$ level considerably differ from the experimental data [16]. Therefore, for further investigations we apply the MP2 method with two above selected basis sets: $6-311 \mathrm{G}(2 d 2 p)$ and 6-311G $(3 d 1 f 3 p)$. The obtained results for RCE presented in Table 3 demonstrate good agreement with experimental data. Therefore, one can conclude that the basis set $2 d 2 p$ is also sufficiently good for large chloroalkanes. It should be noted that both increments $E_{G G}^{\mathrm{XX}}$ and $E_{G T}^{\mathrm{XX}}$ (Table 3) are negative, and consequently, lower the value of the conformational energy. These increments are less sensitive to the basis set size than the additivity increments $E_{G}^{\mathrm{XX}}$ and $E_{G}^{\mathrm{XY}}$. Vice versa, the additivity increment $E_{G G^{\prime}}^{\mathrm{XX}}$ is extremely destabilizing. It is also evident that the existence of $E_{G G}^{\mathrm{XX}}, E_{G G^{\prime}}^{\mathrm{XX}}$, and $E_{G T}^{\mathrm{XX}}$ increments is a consequence of cooperative effects in a 
Table 3. RCE and additivity increments (kcal/mol) obtained from ab initio calculations.

\begin{tabular}{|c|c|c|c|c|}
\hline \multirow[t]{2}{*}{ Chloroalkanes } & \multicolumn{4}{|c|}{ RCE and additivity increments } \\
\hline & $\mathrm{HF} / 6-31 \mathrm{G}(d)$ & $\mathrm{MP} 2 / 6-311 \mathrm{G}(2 d 2 p)$ & MP2/6-311G(3d1f3p) & Exp. data \\
\hline \multicolumn{5}{|l|}{ 1,2-dichloroethane } \\
\hline$E_{G}-E_{T}=E_{G}^{\mathrm{XX}}(\mathrm{X}=\mathrm{Cl})$ & 1.91 & 1.51 & 1.18 & $1.1 \pm 0.1[11]$ \\
\hline \multicolumn{5}{|l|}{ 1-chloropropane } \\
\hline$E_{G}-E_{T}=E_{G}^{\mathrm{XY}}\left(\mathrm{X}=\mathrm{Cl}, \mathrm{Y}=\mathrm{CH}_{3}\right)$ & 0.36 & -0.15 & -0.24 & $-0.15 \pm 0.01[9]$ \\
\hline \multicolumn{5}{|l|}{ 1,3-dichloropropane } \\
\hline$E_{G T}-E_{T T}$ & -0.40 & -0.88 & -0.96 & -0.5 (upper limit) \\
\hline$E_{G G}-E_{G T}$ & -0.44 & -1.01 & -1.22 & $-1.1 \pm 0.2$ \\
\hline$E_{G G^{\prime}}-E_{G G}$ & 4.71 & - & 4.63 & $>3[16]$ \\
\hline$E_{G T}^{\mathrm{XX}}$ & - & -0.73 & -0.72 & - \\
\hline$E_{G G}^{\mathrm{XX}}$ & - & -1.59 & -1.70 & - \\
\hline$E_{G G^{\prime}}^{\mathrm{XX}}$ & - & - & 2.93 & - \\
\hline
\end{tabular}

Table 4. RCE (kcal/mol) obtained both from quantum-mechanical calculations and additivity rule (Eq. (1) with increments obtained by the indicated methods) for 1,2- and 1,2,3-chloropropanes.

\begin{tabular}{|c|c|c|c|c|c|c|}
\hline \multirow[t]{2}{*}{ Chloroalkanes } & \multirow[t]{2}{*}{$\mathrm{HF} / 6-31 \mathrm{G}(d)$} & \multicolumn{2}{|c|}{$\mathrm{MP} 2 / 6-311 \mathrm{G}$} & \multicolumn{2}{|c|}{ Eq. (1), with increments obtained by } & \multirow[t]{2}{*}{ Exp. data } \\
\hline & & $(2 d 2 p)$ & $(3 d 1 f 3 p)$ & $\mathrm{MP} 2 / 6-311 \mathrm{G}(2 d 2 p)$ & MP2/6-311G(3d1f3p) & \\
\hline \multicolumn{7}{|l|}{ 1,2-dichloropropane } \\
\hline$E_{G^{+}}-E_{A}$ & 1.69 & 1.67 & 1.44 & 1.66 & 1.42 & 1.3 (lower limit) \\
\hline$E_{G^{-}}-E_{A}$ & 1.98 & 1.59 & 1.38 & 1.51 & 1.18 & $0.6 \pm 0.3[17]$ \\
\hline \multicolumn{7}{|c|}{ 1,2,3-trichloropropane } \\
\hline$E_{T T}-E_{G G}$ & 2.57 & - & 3.04 & 3.40 & 3.36 & $3.0[18]$ \\
\hline$E_{T G}-E_{G G}$ & 0.34 & - & 1.01 & 1.16 & 1.22 & $0.7 \pm 0.2[19]$ \\
\hline$E_{G T}-E_{G G}$ & 2.0 & - & 2.23 & 2.52 & 2.40 & $1.8 \pm 0.5[19]$ \\
\hline
\end{tabular}

complex molecular system resulting from nonbonded interactions of end groups.

As shown previously in [11] the zero point energy does not differ for conformations used in evaluation of the additivity increments. Consequently, one can conclude that vibrations do not influence the obtained results.

\subsection{Verification of the additivity rule}

The molecules of 1,2-dichloropropane and 1,2,3-trichloropropane were used in order to check the transferability of additivity increments. The relative energies of different conformers of an individual molecule calculated using the additivity rule (1) and direct MP2 calculations as well as experimental data are presented in Table 4. The comparison shows that the arrangement of conformational energies of 1,2-dichloropropanes (Fig. 3) obtained using MP2 on the contrary to HF is in good agreement with experimental data. However, the values of RCE for two basis sets chosen exceed the experimental estimates. The comparison of RCE values obtained from MP2 calculations and Eq. (1) using earlier estimated increments $E_{G}^{\mathrm{XX}}$ and $E_{G}^{\mathrm{XY}}$ (Ta-<smiles>CC1(C)C(Cl)(Cl)C2(C)CC1(C)C2(C)C</smiles>

G+

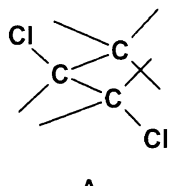

A

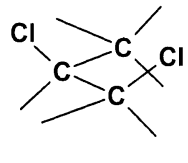

G-
Fig. 3. Conformations of 1,2-dichloropropane.

ble 4) shows slightly different results for $G$ conformer, especially in the case of a larger basis set. The similar results have been obtained for the conformations of 1,2,3-trichloropropane having the lowest energy: $T T$, $T G, G T$, and $G G$ (Fig. 4). The experimental data from gas-phase electron diffraction indicates the $G G$ form as the lowest. The results presented in Table 4 show that all methods used give the correct arrangement of conformational energies. However, the RCE values calculated by the HF method are smaller (particularly for the $T G$ conformer) both than experimental [19] and molecular mechanics [18] estimates. The RCE calculated using the additivity formula with respect to conformation $G G$ are increased almost in the same extent for all forms if compared with MP2 results. Therefore, it can be expected that correlation effects taken into account in MP2 calculations better de- 


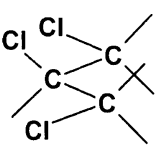

TT

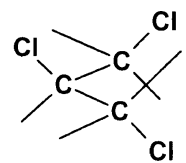

GG

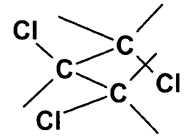

TG

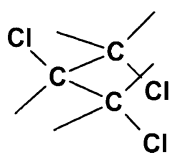

GG'-

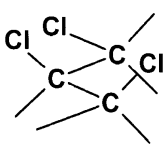

GT

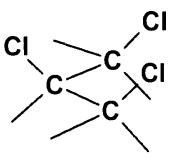

GG'+
Fig. 4. Conformations of 1,2,3-trichloropropane.

scribe intramolecular interactions in the molecule than the additivity scheme, and as a result, we have the rise of the energy of the $G G$ conformer. The stabilizing character of the $E_{G G}^{\mathrm{XX}}$ increment, estimated from 1,3dichloropropane, may be exaggerated. The values of increments $E_{G}^{\mathrm{XX}}$ and $E_{G}^{\mathrm{XY}}$ estimated from MP2 calculations of 1,2- and 1,2,3-chloropropanes are more positive than the values presented in Table 3. However, $E_{G G}^{\mathrm{XX}}$ and $E_{G T}^{\mathrm{XX}}$ are constant and do not depend on the number and location of the substituents. In spite of the obtained differences in the value of additivity increments calculated using different basis sets, it follows from the results obtained for 1,2-dichloropropane and 1,2,3-trichloropropane that they can be used for prediction of the RCE when conditions $E_{G}^{\mathrm{XX}}>0$, $E_{G}^{\mathrm{XY}}<0, E_{G T}^{\mathrm{XX}}<-E_{G}^{\mathrm{XY}}$, and $E_{G G}^{\mathrm{XX}}<-2 E_{G}^{\mathrm{XY}}$ $\left(\mathrm{X}=\mathrm{Cl}, \mathrm{Y}=\mathrm{CH}_{3}\right)$ are satisfied. The above-presented criteria for additivity increments do not depend on the size of the basis set. The analysis of additivity increments $E_{G}^{\mathrm{XY}}$ (Table 1) based on the criteria suggested above also confirm the presumption that the inclusion of the polarization functions is very important for conformational energy calculations.

\section{Conclusions}

The study shows that the calculated values of additivity increments $E_{G}^{\mathrm{XY}}, E_{G}^{\mathrm{XX}}, E_{G T}^{\mathrm{XX}}, E_{G G}^{\mathrm{XX}}$, and $E_{G G^{\prime}}^{\mathrm{XX}}$ $\left(\mathrm{X}=\mathrm{Cl}, \mathrm{Y}=\mathrm{CH}_{3}\right)$ are sensitive to the method and basis sets used. Only the results obtained using the MP2 method with geometry optimization and basis sets including polarization functions are in the scope with experimental estimates. In spite of some differences obtained for values of the additivity increments the arrangement of different conformational configu- rations of a molecule on the energy scale is correctly reflected when increments satisfy the following criteria: $E_{G}^{\mathrm{XX}}>0, E_{G}^{\mathrm{XY}}<0, E_{G T}^{\mathrm{XX}}<-E_{G}^{\mathrm{XY}}$, and $E_{G G}^{\mathrm{XX}}<-2 E_{G}^{\mathrm{XY}}\left(\mathrm{X}=\mathrm{Cl}, \mathrm{Y}=\mathrm{CH}_{3}\right)$. This can be considered as an argument that quantum-mechanical methods can be used for evaluation of the increments of quantum-mechanically based additivity schemes for prediction of the relative conformational energies of saturated chloroalkanes.

\section{References}

[1] D. Šatkovskienė, Int. J. Quantum Chem. 91, 5 (2003).

[2] R. Jankauskas, P. Pipiraitè, and D. Šatkovskienè, Lithuanian J. Phys. 42, 87 (2002).

[3] S. Rodgers and G.S. Buckley, J. Fluorine Chem. 21, 89 (1982).

[4] M.W. Schmidt, K.K. Baldridge, J.A. Boatz, S.T. Elbert, M.S. Gordon, J.J. Jensen, S. Koseki, N. Matsunaga, K.A. Nguyen, S. Su, T.L. Windus, M. Dupuis, and J.A. Montgomery, J. Comput. Chem. 14, 1347 (1993).

[5] A.A. Granovsky, http://classic.chem.msu. su/gran/gamess/index.html

[6] J.R. Durig, S.E. Godbey, and J.F. Sullivan, J. Chem. Phys. 80, 5983 (1984).

[7] K. Yamanouchi, M. Sugie, K. Takeo, C. Matsumura, and K. Kuchitsu, J. Phys. Chem. 88, 2315 (1984).

[8] W.A. Herrebout and B.J. Van der Vaken, J. Phys. Chem. 100, 9671(1996).

[9] J.R. Durig, X. Zhu, and S. Shen, J. Mol. Struct. 570, 1 (2001).

[10] R.A. Friesner, R.B. Murphy, M.D. Beachy, M.N. Ringnalda, W.T. Pollard, B.D. Dunietz, and Y. Cao, J. Phys. Chem. A 103, 1914 (1999).

[11] K.B. Wiberg, T.A. Keith, M.J. Frisch, and M.A. Murcko, J. Phys. Chem. 99, 9072 (1995).

[12] R. Stolevik and K. Hagen, J. Mol. Struct. 352/353, 23 (1995.)

[13] S. Saebo and P. Pulay, J. Chem. Phys. 86, 914 (1987).

[14] K. Kveseth, Acta Chem. Scand. A. 29, 307 (1975).

[15] K.B. Wiberg and M.A. Murcko, J. Phys. Chem. 91, 3616 (1987).

[16] S. Grindheim and R. Stolevik, Acta Chem. Scand. A 30, 625 (1976).

[17] S.H. Schei and R. Stolevik, J. Mol. Struct. 128, 171 (1985)

[18] P.E. Farup and R. Stolevik, Acta Chem. Scand. A 28, 871 (1974).

[19] T. Rydland and R. Stolevik, J. Mol. Struct. 105, 157 (1983) 


\title{
KVANTMECHANINIS KONFORMACINĖS ENERGIJOS ADITYVIŲJŲ PRIEAUGIU IVERTINIMAS: CHLOROALKANAI
}

\author{
D. Šatkovskienė, P. Pipiraitė, R. Jankauskas, J. Šulskus
}

Vilniaus universitetas, Vilnius, Lietuva

\section{Santrauka}

Kvantmechaniniais metodais tyrinèta chloroalkanu konformacinès energijos verčių adityvumo taisyklè, pagal kurią konformacinè energija gali būti išreikšta atskirų konformacinių segmentụ ir jų seku energijos verčiu suma. Ivertinti konformacinès energijos adityviuju prieaugiu $E_{G}^{\mathrm{XY}}\left(\mathrm{X}, \mathrm{Y}=\mathrm{CH}_{3}, \mathrm{Cl}\right), E_{G T}^{\mathrm{XY}}, E_{G G}^{\mathrm{XY}}$, $E_{G G^{\prime}}^{\mathrm{XY}}(\mathrm{X}=\mathrm{Y}=\mathrm{Cl})$ didumai. Skaičiuojant nustatyta, kad HF metodo tikslumas nėra pakankamas chloroalkanų konformacinès energijos vertėms rasti. Juo apskaičiuoto prieaugio $E_{G}^{\mathrm{XY}}(\mathrm{X}=\mathrm{Cl}$, $\left.\mathrm{Y}=\mathrm{CH}_{3}, \mathrm{Cl}\right)$ ženklas yra neteisingas, o prieaugio $E_{G}^{\mathrm{XX}}(\mathrm{X}=\mathrm{Cl})$ vertè yra per didelè. Parodyta, kad tik atsižvelgus i elektronu koreliaciją ir panaudojus pakankamai plačias atominių funkcijų bazes
(6-311G $(2 d, 2 p)$ ir 6-311G(3d,1f,3p), galima gana tiksliai ivertinti konformacines energijas ir apskaičiuoti adityviuosius prieaugius. Surasti tam tikri sąryšiai tarp atskirų konformacinès energijos prieaugių, užtikrinantys adityvumo taisyklès sèkmę prognozuojant chloroalkanu konformacinès energijos vertes. Sudètingu chloroalkanu atskiru konformeru reliatyvios energijos vertès, rastos taikant adityvumo taisyklę, palygintos su eksperimentiniu matavimu ir kvantmechaniniu skaičiavimu rezultatais. Parodyta, kad kvantmechaniškai ịvertinti konformaciniu segmentų ir jų sekų energijų prieaugiai gali būti panaudoti adityviosiose schemose, skirtose chloroalkanu konformacinių energijų išsidèstymui numatyti. 